\title{
Motivational Effect of Communication Technologies in Connectivist Science Education
}

\author{
Eva Trnova, Masaryk University, Czech Republic \\ Josef Trna, Masaryk University, Czech Republic
}

\begin{abstract}
The paper presents our long-term research results of the motivational effect of communication technologies on connectivist technology in science education. Motivation of students is an essential prerequisite for effective science education. Fast development in communication technologies strongly influences science education. The pedagogical theory of connectivism founded by Siemens was born as a response to the rapid development of information and communication technologies. Thus a need occurred to examine these connectivist influences on science and technology education. This study presents a research which focused on identification of motivational connectivist factors and determination of their influence on science education. We implement our motivational connectivist educational methods and tools into science teaching/learning and teachers training. We created collaborative action research based on ICT as a new motivational connectivist teaching/learning method. The main research method used in this study is design-based research. Practical examples are given.
\end{abstract}

Keywords: action research based on ICT; communication; connectivism; motivation; science education. 


\section{Background, Framework, and Purpose}

Motivation plays a significant role in all human activities and it is an essential prerequisite for effective science education. There are various motivational factors which differ depending on the students' individual needs. With today's young generation which is sometimes being labelled as the Net Generation (Oblinger, D. \&, Oblinger, J., 2005) another motivational factor is connected, namely communication technology. According to a new study from the Kaiser Family Foundation the average young American aged 8-18 now spends seven hours and 38 minutes, practically every waking minute (except for the time in school) consuming media, such as watching TV, listening to music, and using a computer or a smart phone (Kaiser Family Foundation, 2010). The situation in Europe is quite similar. Research results show that the influence the media have on students causes changes in the way they perceive the world - their thinking is restructured (Siemens, 2004; Prensky, 2009; Downes, 2005; D. Oblinger, D. \&, Oblinger J., 2005). That is why the Net Generation differs from the previous generations more than ever and why it is difficult to educate this generation using traditional methods of instruction. Also the teaching methods are more and more influenced by communication technologies. Teachers need to be equipped with new competences and innovated professional skills. They have to be able to implement new contents and become familiar with the new methods and tools of innovative educational technologies. The implementation of design-based research and connectivism is an important part of innovative science educational technologies. These phenomena are presented in our study.

\section{Net Generation}

D. Oblinger and J. Oblinger (2005) describe today's students as the Net Generation. They claim like other authors that children growing up under the influence of ICT have got a unique learning style, preferences and worldviews. Today's students are fundamentally different from the previous generations of learners. The most important differences are:

- They are well visually literate, but their text literacy is not developed enough. Most of the Net Generation students (73\%) prefer to use the Internet to libraries for research and they know how to find valid information on the Web (Online Computer Library Center, 2002).

- They intuitively use a variety of ICT without an instruction manual; therefore their understanding of the technology may be sketchy.

- They prefer speed to accuracy. 
- They do multitask, move quickly from one activity to another and sometimes perform them simultaneously.

- They prefer to learn by doing rather than by being told what to do.

- They learn well through inquiry by themselves or with their peers. This exploratory style enables them to retain information better and to use it in creative, meaningful ways (Tapscott, 1998).

- They often prefer to learn and work in teams. A peer-to-peer approach (help each other) is common.

- They consider peers more credible than teachers in terms of determining what is worth paying attention to (Manuel, 2002).

These differences necessarily have an impact on science education and ways of motivation.

\section{Connectivism}

The finding that today's students have a different learning style has led to the origination of a new pedagogical theory: connectivism which has been called, "A Learning Theory for the Digital Age" (Siemens, 2005). G. Siemens first wrote about connectivism in 2005. Since then, he and S. Downes have worked together to develop the theory and practice of connectivism. G. Siemens defines connectivism as, "a model of learning that acknowledges the tectonic shifts in society where learning is no longer an internal, individualistic activity. How people work and function is altered when new tools are utilized.

The field of education has been slow to recognize both the impact of new learning tools and the environmental changes in what it means to learn. Connectivism provides insight into learning skills and tasks needed for learners to flourish in a digital era” (Siemens, 2005).

G. Siemens (2005) recommends adding connectivism to the already existing pedagogical theories of behaviourism, cognitivism, and constructivism. Each of the above mentioned theories is still well justifiable and can be applied in certain circumstances. Knowing all the existing theories, the teacher can use the method that seems to be the most effective for a particular teaching/learning situation. Communication technologies can be employed within all the above mentioned pedagogical theories, however, connectivism is the one which reflects educational needs of the Net Generation best (Siemens, 2006), as shown in Table 1. 
Traditional views on learning have been questioned by some educators (Downes, 2005; Siemens, 2004). The limits of traditional views of knowledge are highlighted with the development of the Internet. Instead of seeing knowledge as innate, a function of reasoning or experience, connectivism and connectivist knowledge present an alternative source of valid knowledge.

According to S. Downes (2005), connectivist knowledge networks possess four traits:

Diversity: Is the widest possible spectrum of points of view revealed?

Autonomy: Were the individual knower's contributing to the interaction of their own accord, according to their own knowledge, values and decisions, or were they acting at the behest of some external agency seeking to magnify a certain point of view through quantity rather than reason and reflection?

Interactivity: Is the knowledge being produced the product of an interaction between the members, or is it a (mere) aggregation of the members' perspectives?

Openness: Is there a mechanism that allows a given perspective to be entered into the system, to be heard and interacted with by others?

In accordance with the above stated principles, in 2005 G. Siemens (2005) identified 8 principles of connectivism:

- Learning and knowledge rests in diversity of opinions

- Learning is a process of connecting

- Learning may reside in non-human appliances

- Capacity to know more is more critical than what is currently known

- Nurturing and maintaining connections is needed for continual learning

- Ability to see connections between fields, ideas, and concepts is a core skill

- Accurate, up-to-date knowledge is the aim of all connectivist learning

- Decision-making is a learning process. What we know today may change tomorrow. The right decision today may be the wrong decision tomorrow.

S. Downes (2006) applies the network theory to the network pedagogy and formulates S. Downes educational theory:

- A good student learns by practice, practice and reflection

- A good teacher teaches by demonstration and modelling 
- The essence of being a good teacher is to be the sort of person you want your students to become

- The most important learning outcome is a good and happy life

Table 1. Learning theories (Siemens, 2006, p. 36)

\begin{tabular}{|c|c|c|c|c|}
\hline Property & Behaviourism & Cognitivism & Constructivism & Connectivism \\
\hline $\begin{array}{l}\text { How does } \\
\text { learning occur? }\end{array}$ & $\begin{array}{l}\text { Black box - } \\
\text { observable } \\
\text { behaviour main } \\
\text { focus }\end{array}$ & $\begin{array}{l}\text { Structured, } \\
\text { computational }\end{array}$ & $\begin{array}{l}\text { Social, meaning } \\
\text { created by each } \\
\text { learner (personal) }\end{array}$ & $\begin{array}{l}\text { Distributed within } \\
\text { a network, social, } \\
\text { technologically } \\
\text { enhanced, } \\
\text { recognizing and } \\
\text { interpreting } \\
\text { patterns }\end{array}$ \\
\hline $\begin{array}{l}\text { Influencing } \\
\text { factors }\end{array}$ & $\begin{array}{l}\text { Nature of reward, } \\
\text { punishment, } \\
\text { stimuli }\end{array}$ & $\begin{array}{l}\text { Existing schema, } \\
\text { previous } \\
\text { experiences }\end{array}$ & $\begin{array}{l}\text { Engagement, } \\
\text { participation, } \\
\text { social, cultural }\end{array}$ & $\begin{array}{l}\text { Diversity of } \\
\text { network }\end{array}$ \\
\hline $\begin{array}{l}\text { What is the } \\
\text { role of } \\
\text { memory? }\end{array}$ & $\begin{array}{l}\text { Memory is the } \\
\text { hardwiring of } \\
\text { repeated } \\
\text { experiences - } \\
\text { where reward and } \\
\text { punishment are } \\
\text { most influential }\end{array}$ & $\begin{array}{l}\text { Encoding, storage, } \\
\text { retrieval }\end{array}$ & $\begin{array}{l}\text { Prior knowledge } \\
\text { remixed to current } \\
\text { context }\end{array}$ & $\begin{array}{l}\text { Adaptive patterns, } \\
\text { representative of } \\
\text { current state, } \\
\text { existing in } \\
\text { networks }\end{array}$ \\
\hline $\begin{array}{l}\text { How does } \\
\text { transfer occur? }\end{array}$ & Stimulus, response & $\begin{array}{l}\text { Duplicating } \\
\text { knowledge } \\
\text { constructs of } \\
\text { "knower" }\end{array}$ & Socialization & $\begin{array}{l}\text { Connecting to } \\
\text { (adding) nodes }\end{array}$ \\
\hline $\begin{array}{l}\text { Types of } \\
\text { learning best } \\
\text { explained }\end{array}$ & $\begin{array}{l}\text { Task-based } \\
\text { learning }\end{array}$ & $\begin{array}{l}\text { Reasoning, clear } \\
\text { objectives, } \\
\text { problem solving }\end{array}$ & $\begin{array}{l}\text { Social, vague ("ill } \\
\text { defined") }\end{array}$ & $\begin{array}{l}\text { Complex } \\
\text { learning, rapid } \\
\text { changing core, } \\
\text { diverse } \\
\text { knowledge } \\
\text { sources }\end{array}$ \\
\hline
\end{tabular}

Connectivism reflects the influence of ICT on education, therefore also on science education. It uses ICT, social networks, etc. and thus it is a suitable educational approach for instruction 
of the Net generation students because of the respect for their learning style. One of the principles of connectivism to which teachers should react in their teaching is that the ability to learn what we need for tomorrow is more important than what we know today. The thesis of „know-where" substitutes the present theses "know-what" and "know-how". We should be teaching our students not only finished knowledge but also the path to it and skills to assess it.

We use these theories to identify connectivist motivation factors and to determine their influence on science education; to develop motivational connectivist educational methods and tools; implementation of to implement motivational connectivist methods and tools into science teaching/learning and teachers training. We developed collaborative action research based on ICT as an important method for the development of teachers ' professional competencies in the sphere of students' motivation. Design-based research is the main research method used in this study.

\section{Rationales and Research Questions}

Today science education plays an important role in educational systems and in many systems it has the goal of enhancing scientific literacy in students (American Association for the Advancement of Science, 1989), but the interest of students in science has been significantly decreasing. There are many causes and factors of this negative situation but the way science is taught in schools and the different learning style of today's learners are the main reasons. In this context it is necessary to consider how to change teaching methods and increase students' motivation for science (Rocard et al, 2007). The way how to increase the motivation of students in science is to respect the stated generation differences and understand what they prefer, what they are interested in, and how they learn. Students learn more effectively when taught in accordance with their learning style preferences and when their worldviews are acknowledged. So it is necessary to change teaching methods and materials to accommodate the Net Generation learners better and to correlate them with improvements in students' attitudes and performances. Therefore the need arose to examine possible connectivist influences on science education.

Our research focuses on the following issues: 
- Identification of motivational effect of communication technologies on connectivist technology in science education

- Creation of connectivist educational methods and tools in science education

- Implementation of connectivist educational methods and tools into science teaching/learning and science teachers training

\section{Research Methods}

To monitor the motivational effect of communication technologies on connectivist technology in science education, we used a method of a design-based research. It is a development research. This research differs from other types of research. Unlike the empirical research, hypothesis and research questions are not determined, but the problem is defined to be solved. Design-based research is a new trend in educational research. The used methodology can be described as a cycle: analysis of a practical problem, development of solutions, iterative testing of solutions, reflection and implementation (Reeves, 2006).

The core of design-based research is to focus on the creation of a new product. This research offers solutions to problems that have only been solved partially so far, and relevant instruments and methods (Järvinen, 2004). The main advantage of the design-based research is its close connection with educational practice. The above-mentioned reasons led us to use design-based research to address the issue of motivational effect of communication technologies on connectivist technology in science education.

Sufficient methods/tools for our research also were:

- Factor analysis

- Didactic analysis and development of connectivist teaching methods and tools

- Collaborative action research based on ICT (Trna \&, Trnova, 2010) for verification of efficiency of the developed connectivist teaching/learning methods and tools

- The data generating methods: questionnaires, observations, interviews, tests, portfolios etc.

\section{Results and Discussion}

Our design-based research resulted in the development of collaborative action research based on ICT as a connectivist form of action research which can be used by teachers in long distance cooperation. Drawing on our experience, the international form of this collaborative 
action research based on ICT, where students and teachers from different countries cooperated, has proved successful.

Collaborative action research based on ICT was carried out in the following form: it was carried out on-line in two classes, one class in the Czech Republic and the other one in Portugal; it was prepared and managed by two cooperating teachers in the Czech Republic and in Portugal; teaching was carried on at the same time with the use of on-line communication (Skype etc.).

As an example we would like to present a communication between the teachers in the phase of preparation, and a communication between the students when talking about the results of the experiments they planned for and carried out together. We are presenting the texts in their original version without any grammatical changes.

\section{Teachers' communication:}

Teacher A: "[...] After being away for some time, I'm sending you the first materials I have prepared. [...]I'm sending you a reduced version of the Portuguese Biology syllabus, adopted from the Ministry of Education. I'm also enclosing a draft of pre-test. Is it possible for you to have a look at it and tell me what do you think? [...]

Teacher B: "[...] I agree with a draft of pre-test and I'm sending you some next materials. I have found very good materials in English version about experiments. They are in the attachment. I hope that you have received my first e-mail. Please write what next is necessary to do. [...]"

\section{Students' communication:}

Students change idea about the experiments

[10:46:19] Veronika: let's do some questions?

[10:46: 32] Margarida: yes

[10:46:47] Veronika: first question

[10:47:41] Veronika: explain why the plant was placed in the dark for 3 days and then he moved it to an illuminated place.

[10:48:03] Margarida: To ensure that there isn't starch before starting the experiment, thereby ensuring that the results are due to the action of the light. 
International cooperation between the teachers and among the students where collaborative action research based on ICT was used brought about strong motivation of all the participants. Tangible evidence of this strong motivation can be found in the open answers in the questionnaire below as well as in the findings of the questionnaire research stated in Table 2.

\section{The most frequent open responses from the questionnaire:}

"It was fine to read worksheets and discuss about tasks with Portuguese friends"....

"That was great experience to work with our Portuguese classmates."

"I was curious about this project, it was really interesting."

"Enthusiasm - because it's amazing to do project online with students from Portugal."

"I'm very happy that I could be a partner in this project."

Table 2. Responses by Portuguese/Czech students - motivation

\begin{tabular}{|l|c|c|c|c|c|}
\hline $\begin{array}{l}\text { In the statements listed below there are some of the aspects related to the activities } \\
\text { shared with your Czech colleagues. Choose the option which best expresses your } \\
\text { opinion. }\end{array}$ & $\begin{array}{l}\text { Disagr } \\
\text { ee }\end{array}$ & $\begin{array}{l}\text { Partially } \\
\text { Agree }\end{array}$ & Agree & $\begin{array}{l}\text { Strongly } \\
\text { Agree }\end{array}$ & $\begin{array}{l}\text { No } \\
\text { opinion }\end{array}$ \\
\hline N=27/21 & $7 \%$ & $33 \%$ & $42 \%$ & $14 \%$ & $4 \%$ \\
\hline $\begin{array}{l}\text { The partnership helped you } \\
\text { to better understand certain } \\
\text { aspects of this topic. }\end{array}$ & $0 \%$ & $29 \%$ & $47 \%$ & $19 \%$ & $5 \%$ \\
\hline $\begin{array}{l}\text { The fact that various } \\
\text { activities were undertaken in } \\
\text { partnership with colleagues, } \\
\text { increased your interest in } \\
\text { studying this topic }\end{array}$ & $3 \%$ & $30 \%$ & $52 \%$ & $15 \%$ & $0 \%$ \\
\hline $\begin{array}{l}\text { The main } \\
\text { communication tools (e-mail, } \\
\text { MSN, Face book, Skype } \\
\text { stimulated sharing ideas and }\end{array}$ & $0 \%$ & $29 \%$ & $47 \%$ & $19 \%$ & $1 \%$ \\
\hline
\end{tabular}


experience.

The questionnaire was focused on students' reflections on this innovative bilateral collaboration with ICT use. Their answers indicate high level of both motivation and engagement in the educational process. According to the test results and also in the students' opinion they learnt a great deal.

Students' view of the teachers' work in on-line environment and their ability to manage unusual instruction is also very interesting (see Table 3):

Table 3. Responses of Portuguese/Czech students - teachers' work

\begin{tabular}{|l|l|l|l|l|l|}
\hline $\begin{array}{l}\text { Your teacher's performance (regarding the aspects listed below) contributed to } \\
\text { learning the topic in an online environment. Choose the option that best expresses } \\
\text { your opinion. }\end{array}$ & $\begin{array}{l}\text { Disagr } \\
\text { ee }\end{array}$ & $\begin{array}{l}\text { Partially } \\
\text { Agree }\end{array}$ & Agree & $\begin{array}{l}\text { Strongly } \\
\text { Agree }\end{array}$ & $\begin{array}{l}\text { No } \\
\text { opinion }\end{array}$ \\
\hline N=27/21 showed & & & $33 \%$ & $63 \%$ & $0 \%$ \\
\hline $\begin{array}{l}\text { The teacher sharing } \\
\text { enthusiasm in students } \\
\text { experiences between } \\
\text { from both countries. }\end{array}$ & $0 \%$ & $14 \%$ & $33 \%$ & $48 \%$ & $5 \%$ \\
\hline $\begin{array}{l}\text { The teacher demonstrated } a \\
\text { capacity to motivate students } \\
\text { in this topic. }\end{array}$ & $0 \%$ & $7 \%$ & $63 \%$ & $30 \%$ & $0 \%$ \\
\hline $\begin{array}{l}\text { The teacher's interaction and } \\
\text { monitoring of students' on-line } \\
\text { work was effective. }\end{array}$ & $0 \%$ & $11 \%$ & $33 \%$ & $56 \%$ & $0 \%$ \\
\hline $\begin{array}{l}\text { The teacher encouraged } \\
\text { interaction both within and } \\
\text { between groups. }\end{array}$ & $0 \%$ & $11 \%$ & $43 \%$ & $33 \%$ & $5 \%$ \\
\hline
\end{tabular}


Students' responses in the questionnaire prove that their mutual communication and the use of ICT are highly motivating for the learners and that the students learn more effectively when they are taught in accordance with their learning style.

\section{Conclusions}

The main outcomes of the research and implementation of connectivist methods and tools into science education are:

- Strong motivation of students and teachers especially through communication with their peers in other countries, new information, applications of knowledge from abroad, personal contacts etc.

- Exchange of experience between teachers (teaching methods) by comparing curricular material (textbooks, learning tasks, experimentation etc.)

- Employing new educational methods

- Acquisition of subject knowledge and skills

- Team collaboration among teachers inside the partner schools (support with ICT, English, organisation of lessons etc.)

- Team collaboration among students within the partner schools (support with ICT, organisation of lessons etc.)

With the help of design-based research, suitable teaching methods and tools could be developed for teachers to realize science education in the most efficient and motivational way (Hodson, 1988). We may anticipate that importance of connectivist methods and tools will grow and that students and teachers will work creatively using ICT even more. Our research results indicate that students learned with interest, and their knowledge and skills were better than we would expect using standard methods free of connectivism. On the basis of the results of our research, we can conclude that the connectivist methods and tools produced very positive outcomes for students and significantly contributed to the development of competences of teachers for science education. 


\section{References}

American Association for the Advancement of Science. (1989). Science for all Americans. Washington D. C.: AAAS.

Downes, S. (2005, December 12). An introduction to connective knowledge. Retrieved March 12, 2013, from http://www.downes.ca/cgi-bin/page.cgi?post=33034

Downes, S. (2006). Learning networks and connective knowledge. Retrieved March 12, 2013, from http://it.coe.uga.edu/itforum/paper92/paper92.html

Hodson, D. (1988). Experiments in science and science teaching. Educational Philosophy and Theory, 20, 253-66.

Järvinen, P. (2004). On Research Methods. Tampere, Finland: Opinpajan Kirja.

Kaiser Family Foundation, (2010). Generation M2: Media in the Lives of 8-to 18-Year-Olds. Retrieved March 12, 2013, from http://www.kff.org/entmedia/upload/8010.pdf Manuel, K. (2002). Teaching Information Literacy to Generation Y. NY: Haworth Press. Oblinger, D. \&, Oblinger J. (2005). Educating the Net Generation. EDUCAUSE. Retrieved March 12, 2013, from http://www.educause.edu/educatingthenetgen/

Online Computer Library Center. (2002). How Academic Librarians Can Influence Students' Web-Based Information Choices. OCLC white paper on the information habits of college students. Retrieved March 12, 2013, from http://www5.oclc.org/downloads/community/informationhabits.pdf

Prensky, M. (2009). H. Sapiens Digital: From Digital Immigrants and Digital Natives to Digital Wisdom. Innovate [online]. 2009, V, 3, [cit. 2011-08-28]. Retrieved March 12, 2013, from: http://innovateonline.info/pdf/vol5_issue3/H._Sapiens_Digital_From_Digital_Immigrants_and_Digital_Natives_to_Digital_Wisdom.pdf

Reeves, T. C. (2006). Design research from the technology perspective. In Akker, J. V., Gravemeijer, K., McKenney, S., \& Nieveen, N. (Eds.). Educational design research. (pp. 86-109). London, UK: Routledge.

Rocard, M., Csermely, P., Jorde, D., Lenzen, D., Walberg-Herniksson, H., \& and Hemmo, V. (2007). Science Education NOW: A Renewed Pedagogy for the Future of Europe. Retrieved March 12, 2013, from http://ec.europa.eu/research/sciencesociety/document_library/pdf_06/report-rocard-on-science-education_en.pdf

Siemens, G. (2004). Connectivism: A learning theory for the digital age. International Journal of Instructional Technology and Distance Learning. Retrieved March 12, 2013, from http://www.itdl.org/Journal/Jan_05/article01.htm 
Siemens G. (2005). Connectivism: A Learning Theory for the Digital Age. Elearnspace.

Retrieved March 12, 2013, from

http://www.elearnspace.org/Articles/connectivism.htm

Siemens, George. (2006, November 12). Connectivism: Learning Theory or Pastime for the Self-Amused. Elearnspace. Retrieved March 12, 2013, from http://www.elearnspace.org/Articles/connectivism_self-amused.htm

Tapscott, D. (1998). Growing Up Digital: The Rise of the Net Generation. NY: McGraw Hill.

Trna, J., Trnova, E. (2010). ICT-based collaborative action research in science education. In IMSCI'10. The 4th International Multi-Conference on Society, Cybernetics and Informatics. Proceedings. Volume I. (pp. 68-70). Orlando, USA: International Institute of Informatics and Systematics.

\section{Acknowledgements}

The study was initiated within the project "EDUCOLAND“(CZ.1.07/1.3.41/02.0043). 